\title{
PROFITABILITY OF ISLAMIC BANKS: A PANEL DATA
} ANALYSIS

\author{
Amine Bakkeri \\ Faculty of Economics and Management of Sfax \\ University of Sfax, Tunisia \\ E-mail: bakkeriamine@gmail.com
}

\author{
Abdelhakim Ben Ali \\ Faculty of Law, Economics and Management of Jendouba \\ University of Jendouba, Tunisia \\ E-mail:benali.abdelhakim@gmail.com
}

\begin{abstract}
This article aims to examine the impact of internal and external factors on the profitability of 30 Islamic banks operating in the Middle East and North Africa over a period from 2005 till 2018. We use the OLS method according to Panel data. Empirical results indicate that the quality of management, liquidity, and capitalization, quality of services, the presence of women and the competence of staff are significant determinants of profitability. The other determinants including diversification, size and inflation have no significant effect on the Islamic banks' profitability.
\end{abstract}

Keywords: Profitability, Islamic banks, Panel data, Middle East, North Africa.

JEL Classification Codes: G21, G24, C33, D02.

\section{INTRODUCTION}

Islamic finance is currently enjoying remarkable success after its strong resistance to loss failures following the outbreak of the supreme crisis in 2008. This phenomenon appears to be a real alternative to classical finance (Ahmed, 2010). It revolves around a philosophy that is specific to it and allows meeting and satisfying the needs of customers via its legitimacy drawn from the principles imposed by Sharia by sharing the risks and the profits with the customers. Islamic finance, which offers Sharia-compatible products, is attracting the attention of investors, specialists in the field, and policy makers (Ougoujil \& Rigar, 2018).

This study is part of the works dealing with the question related to the determinants of profitability within Islamic banks, the objective of which concerns the impact of external and internal factors' impact on the Islamic banks' profitability. Unlike previous research, our work proposes and integrates new factors that affect the bank profitability, in particular the service's quality, the women's presence, and the competence of staff.

To answer our research question, this paper is distributed as follows: the section will present the literature review and the research hypotheses. In the second part, we present the 
research methodology, the results and their interpretations. We will end with the conclusion and the limits of our research.

\section{BACKGROUND AND HYPOTHESES}

Theoretical and empirical contributions in the literature have shown that the profitability of Islamic or conventional banks is assessed by criteria related to the internal management of the banks as well as the environmental factors in which these institutions operate (Jadoon et al., 2019; Babalola et al., 2012; Sufian, 2010; Wasiuzzaman et al., 2013). The latter use the use of a variety of external and internal factors that may affect the Islamic banks' profitability.

\section{The quality of banking management}

Abduh et al. (2013) studied the determinants of profitability in Malaysia. They have shown that the development of financial markets, the size of the bank, market concentration and inflation have a positive and significant effect on bank profitability. The latter are called upon to adopt a sound management of cost by exploiting to the best of their resources. The effect of this variable is ambiguous in the literature. Indeed, Sufian (2010) found that the ratio of total overheads to total assets has a negative and significant impact on the Malaysian Islamic banks' profitability. Hassan et al. (2009) found that this ratio has no significant impact on bank profitability. Abduh et al. (2014) indicate a negative and significant effect between banking management quality and the Islamic banks' profitability. Wasiuzzaman et al.(2014) showed that the capital adequacy ratio and asset quality have a negative and significant effect and that liquidity and operational efficiency, inflation and gross domestic product have a significant and positive effect on bank profitability. Similarly, Khan and Ijaz (2014) assess the factors affecting the profitability of Islamic banks during the period 2007 to 2014. The results indicate that capital adequacy, operational efficiency, quality of management and income gross domestic have a significant effect, while inflation has a negative effect on profitability.

$\mathbf{H}_{1}$ : Quality of bank management has a positive and significant effect on the Islamic banks' profitability.

\section{Liquidity}

Eljelly and Elobeed (2013) have shown that only factors such as cost, liquidity and bank size have a positive and significant impact on performance. External factors are insignificant determinants.

Daoud et al. (2016) assessed the banks' performance using the ratio method. The results indicate that capital adequacy, liquidity, operational efficiency are significant ratios of profitability. Credit risk is not a significant variable. Regarding external factors, gross domestic product displays stimulating effects on the Islamic banks' profitability.

Islamic financial institutions face a major constraint on liquidity, which is justified by the absence of an interbank market on which these institutions can manage their liquidity. The solution to this problem lies in the development and standardization of instruments to manage the liquidity of Islamic financial institutions. The majority of studies that have examined the Islamic banks' profitability suggest that Islamic banks should be more liquid and therefore it will be less exposed to liquidity risk. Srairi (2009) reveal a positive effect between liquidity and Islamic Banks' profitability (Samad, 2004). 
$\mathbf{H}_{2}$ : Liquidity has a negative and significant effect on the profitability of Islamic banks.

\section{Capital-adequacy}

Sufian (2010) studied new empirical evidence on the factors that precise the banking sector's profitability in the Republic of Korea over the period 1994-1996. Empirical results show that banks in the Republic of Korea with high capitalization levels are tending to have higher profitability levels. However, the impact of credit is always negative under macroeconomic and financial conditions (Haron, 1996). At the same time, the effect of the economic cycle on bank profitability is mixed. On the one hand, inflation has a pro-cyclical impact, while the gross domestic product has a counter-cyclical influence on the profitability of banks. Dodi et al.(2018) have shown that capital adequacy, credit risk and asset size have a significant and negative effect on bank profitability, while liquidity has a positive and significant impact on the banks' profitability. However, only external factors have a significant and positive effect, while gross domestic product has a negative and significant effect on the profitability of banks. Hanif et al. (2012) and AlTamimi et al. (2011) compared profitability in conventional and Islamic banks. the results indicate that the capital adequacy ratio is a significant factor in profitability, size has no effect and operational efficiency has a negative impact on bank profitability (Munir, 2017).

Islamic banks must have solid capital to provide them with additional strength to resist the financial crises on one hand, and on the other hand to provide security for depositors' funds during unstable macroeconomic conditions. A high level of equity reflects in fact the degree of solvency of Islamic banks and their capacity to meet their commitments (Zarrouk et al., 2016).

$\mathbf{H}_{3}$ : Capital adequacy has a positive and significant effect on the profitability of Islamic banks.

\section{Quality of service}

The quality of services (customer satisfaction or customer retention) is one of the most important elements at present in the face of increasing competition the quality of service reflects a relationship of trust with customers (Aisyah, 2018; Ali and Raza, 2017).

This relationship reflects in the framework of the priorities of banks to protect their brand image, their reputation which leads to the valuation of their performance (Supiyadi et al., 2019). By adopting strategies and techniques, banks must offer highly qualified and distinguished services to ensure customer loyalty. As banking services are now similar, there are some small parts that make the difference to the clients' ability to answer their queries and provide the services needed in a timely and high-quality manner. Based on these findings, we test the hypothesis that:

$\mathbf{H}_{4}$ : Quality of service has a positive and significant effect on the Islamic banks' profitability.

\section{Women's presence}

In the Middle East and North Africa region, the majority of countries are adopting a proactive policy in favor of women's rights and the elimination of gender inequalities. The gender thus involves adopting and implementing innovative equity measures as well as human resource management based on criteria of competence and performance and on the principles of social justice and equality (Sinha, 2020). General guidelines on integrating gender and diversity in human resources management have several advantages. The institutions are more specifically responsible for developing strategies on gender mainstreaming and for coordinating and 
supervising the implementation of gender-sensitive human resources and mechanisms and management policies. More specifically, the institutions are responsible for developing strategies on gender mainstreaming and for coordinating and overseeing the implementation of gendersensitive human resource management systems and mechanisms (Alazzani,2019). Establishments, mainly banks, insurance companies and private companies, give importance to the presence of women in the workforce. However, the appreciation of the role of women reflects the adoption of a culture of gender diversity, which enshrines the principle of equality and equal opportunities between the sexes. With intense competition, institutions seek to attract talent of all genders to ensure continuity and efficiency.

$\mathbf{H}_{5}$ : Presence of women has a positive and significant effect on the Islamic banks' profitability.

\section{Market share}

The literature indicates that the best performing banks are associated with banks with the lowest market share; (Sufian \& Habibullah, 2010; Abduh et al., 2014). In some cases, continued expansion of market share could lead to additional costs and thus lead to inefficiencies. Sufian (2009) deduced a negative relationship between bank profitability and market share (Petria et al., 2015). Abdel-Hameed (2003) analyzed the effect of bank characteristics and the general financial environment on the Islamic banks' performance. His study has shown that by controlling the macroeconomic environment, the financial structure of the market and taxation negatively affect profitability. Favorable macroeconomic conditions have a positive and significant impact on the profitability of Islamic banks. Abduh et al. (2013) studied the determinants of profitability in Malaysia and showed that the development of financial markets, bank size, market concentration and inflation have a positive and significant effect on profitability banking.

$\mathbf{H}_{6}$ : Market share has a positive and significant effect on the Islamic banks' profitability.

\section{Diversification}

The diversification reduces risk and helps minimize the risks they face Islamic banks by building a diversified portfolio of holdings. It can be a source of profit for Islamic financial institutions as these banks offer a diverse range of products and services or a source of costs. Petria et al. (2015) tested the internal and external determinants of the profitability of Member States during the period 2004-2011. The results of their study have shown that capital adequacy, size, diversification and gross domestic product have a positive and significant impact on the profitability of European banks and that liquidity, credit risk and inflation negatively affect performance banking.

On the one hand, diversification can be a source of cost for newly created banks, which can weigh heavily on the bank's situation especially during critical moments. For a bank whose strategies are clear, transparency in investment matters with the presence of an audit committee and a supervisory board, all these arguments make diversification a source of profit. Diversity of products, differentiation at the service level helps the bank to diversify to take advantage of it.

$\mathbf{H}_{7}$ : Diversification has a negative and significant effect on the Islamic banks' profitability. 


\section{Inflation}

Inflation is widely used in the literature as an external factor that can affect the Islamic banks' profitability. Abduh et al. (2014) analyzed the factors of Islamic banks' profitability over the period 2006-2010 and showed that operational efficiency, inflation have a positive and significant impact on the performance measured by ROA. Using ROE as a measure of profitability, they have shown that operational efficiency and inflation have a negative impact while gross domestic product has a positive effect on the performance of Islamic banks.

In this sense, Sufian et al. (2009) have shown that inflation has a negative relationship with the banks' profitability in Bangladesh. Others like Abduh et al. (2014), Srairi (2009) deduced complex results to see ambiguous.

$\mathbf{H}_{\mathbf{8}}$ : Inflation has a positive and significant effect on the Islamic banks' profitability.

\section{The size of the bank}

This variable is used in several previous works, (Sufian 2010; Khrawish, 2011). Size informs us about the quality of control for cost differences and the ability to diversify. Dodi et al. (2018) examined the effect of factors that contribute to the Islamic banks' profitability in Indonesia over the period 2008 - 2017. The results of the study revealed that Size has a positive effect on ROA and ROE while Capital, Credit Risk and Liquidity had a negative effect on the profitability of the Islamic bank in Indonesia. Likewise, inflation had a positive effect while gross domestic product had no significant effect on the profitability of Islamic banks

Sufian (2010) and Khrawish (2011) argued that large banks should have more economies of scale and reduced the cost of collecting and processing information. Abduh et al. (2014) indicate a non-significant effect of size on the Islamic banks' profitability. Wasiuzzaman (2010) indicates a negative but insignificant relationship between the size of the bank on the profitability.

\section{The staff competence}

Achieving a high level of profitability is conditioned by requirements, mainly the degree of professionalism of the employed workforce. The bank must devote a portion of its profits to the training and remuneration of the team or the employees employed. The lack of competent and qualified personnel exposes the Islamic bank to risks. Institutions tend to give considerable importance to the training and specialization of its staff employed and especially in the field of the Islamic jurisprudence. The majority of banks give importance to the training of executives. The allocation of costs or costs by increasing the volume of services or gains in terms of profitability results from a specialized workforce. In addition, giving a place for the training of the managers, this leads to increase the professional capacities and to create a good climate for the conduct of the business of the bank (Supiyadi et al., 2019). The institution's profitability therefore increases as a result of policies consistent with the quality of the workforce and a staff competence.

\section{Sample and Data}

\section{RESEARCH METHODOLOGY}

Our objective is to study the effect of internal and external factors on the profitability of a sample of 30 Islamic banks operating in the Middle East and North Africa over a period from 2005 to 
2018. Or a number of observation equal to 420. All our data are extracted from annual reports published by Islamic banks, data from the World Bank and the bank-scope database.

\section{Research model and presentation of variables}

In line with the work of Short (1979), our model is a multiple linear regression. Such a linear analysis allows more logical and more robust results. Our model takes the following form:

Profitability $=\alpha+\sum \beta \mathrm{k} \mathrm{X}_{i t}+\varepsilon$ it

with:

Profitability of Islamic banking measured by the return on ROA Assets,

$\mathrm{X}_{i t}$ represents the dependent variables.

So, our model is as follows:

$\mathrm{ROA}_{i t}=\alpha+\beta 1 \mathrm{QGB}_{i t}+\beta 2 \mathrm{LIQ}_{i t}+\beta 3 \mathrm{CB}_{i t}+\beta 4 \mathrm{QS}_{i t}+\beta 5 \mathrm{GENDER}_{i t}+\beta 6 \mathrm{MSH}_{i t}+\beta 7 \mathrm{DIV}_{i t}$ $+\beta 8 \mathrm{INF}_{i t}+\beta 9 \mathrm{SIZE}_{i t}+\beta 10 \mathrm{ST}-\mathrm{COM}_{i t}+\varepsilon_{i t}$

\section{Dependent Variable}

$\mathbf{R O A}_{i t}$ : Return on assets from bank i to instant t. It is expressed as Net Income / Total Assets.

Independent variables

GGB $_{i t}$ : Quality of banking services from bank i to instant $t$ measured by total fees / total assets.

$\mathbf{L I Q}_{i t}$ : Liquidity of the bank from bank $\mathrm{i}$ to instant $\mathrm{t}$ is measured by the ratio of cash / Total Assets.

$\mathbf{C B}_{i t}$ : capitalization from bank i to instant $\mathrm{t}$ measured by book value of equity / Total Assets.

QS $_{i t}$ : Quality of services from banks $\mathrm{i}$ to instant $\mathrm{t}$ defined by evolution of the number of customers. It measured by difference in the number of customers in year $t$ and in year $\mathrm{t}-1$ divided by the number of customers in year $t$ (number of customers in year $t$ - number of customers in year $\mathrm{t}-1)$ / number of customers in year $t$.

GENDER $_{i t}$ : The presences of women in human resources from bank $i$ to instant $t$ measured by the percentage of the number of women in relation to the total staff.

MSH $_{i t}$ : Market share from bank i to instant $t$ measured by the natural logarithm of Total Deposit.

DIV $_{i t}$ : Diversification from bank i to instant $\mathrm{t}$ calculated by Non-interest bearing income / Total Assets.

$\mathbf{I N F}_{i t}$ : Inflation rate calculated by the consumer price index.

Variables of Control

SIZE $_{i t}$ : Size from bank i to instant t measured by the natural logarithm of Total Assets. 
ST-COM ${ }_{i t}$ : staff skills from bank i to instant $\mathrm{t}$ a binary variable which takes the value of the unit if the bank carries out staff training, 0 if not.

\section{RESULTS AND INTERPRETATIONS}

\section{Hausman specification test}

Table 1. Hausman specification test

\begin{tabular}{|c|c|c|c|c|}
\hline & \multicolumn{2}{|c|}{ Coefficients } & & sqrt(diag(V_b- \\
\hline & (b) & $(B)$ & $(b-B)$ & S.E. \\
\hline & FE & RE & Difference & \\
\hline QGB & 0,7456 & 0,6543 & 0,0913 & 0,0002 \\
\hline LIQ & 1,3509 & 0,9844 & 0,3665 & 0,1008 \\
\hline CB & $-1,3456$ & $-1,0765$ & $-0,2691$ & 0.81896 \\
\hline QS & 0,8348 & 0,9653 & $-0,1305$ & 0,0056 \\
\hline GENDER & 1,3654 & 0,7298 & 0,6356 & 0.01026 \\
\hline MSH & $-0,6072$ & 0,8163 & $-1,4235$ & 0,0001 \\
\hline DIV & 1,0134 & 3,0546 & $-2,0412$ & 0,3921 \\
\hline INF & 0,0115 & 1,0056 & $-0,9941$ & 0.0046 \\
\hline SIZE & $-0,0875$ & 0,0778 & $-0,1653$ & 0.1690 \\
\hline ST-COM & 0,9234 & 2,4571 & $-1,5337$ & 0,0034 \\
\hline b = consistent under Ho and Ha; obtained from xtlogit \\
\hline B = inconsistent under Ha, efficient under Ho; obtained from xtlogit \\
\hline chi2 (10) = (b-B)'[(V_b-V_B)^(-1)](b-B) = 8.94 \\
\hline Prob>chi2 = 0.0131 \\
\hline
\end{tabular}

Hausman's test will suggest the use of one of two estimation methods (estimation methods with random or fixed effects). This test makes it possible to determine if the coefficients of the two estimators are statistically different. The idea is that under the null hypothesis of independence between the errors and the explanatory variables, the two estimators are unbiased, so the coefficients should differ little. The result follows a law $\chi^{2}$ with $\mathrm{k}-1$ degree of freedom. The comparison of the tabulated value of $\chi^{2}(\mathrm{k})$ at $95 \%$ with that calculated from the Hausman test can lead us to specify the estimate in fixed or random effect. This test provides us with an idea of the nature of fixed or random effects. The table indicates a probability lower than $10 \%$ which implies that the effects are fixed in our study.

\section{Descriptive statistics and Pearson correlations}

Table 2. Descriptive statistics

\begin{tabular}{|l|l|l|l|l|}
\hline Variables & Min & Max & Mean & Std. Dev. \\
\hline ROA & -0.115 & 0.188 & 0.037 & 2.076 \\
\hline QGB & 0 & 0.724 & 0.343 & 0.243 \\
\hline LIQ & 0 & 0.623 & 0.187 & 0.081 \\
\hline CB & 0.083 & 0.656 & 0.545 & 1.279 \\
\hline
\end{tabular}




\begin{tabular}{|l|l|l|l|l|}
\hline MSH & 3.01 & 5.152 & 2.065 & 0.097 \\
\hline QS & 0.17 & 0.336 & 0.211 & 0.043 \\
\hline GENDER & 0.12 & 0.448 & 0.324 & 0.115 \\
\hline DIV & -3.167 & 5.019 & 0.933 & 0.615 \\
\hline INF & 3.452 & 8.589 & 5.016 & 0.407 \\
\hline ZIZE & 1.058 & 9.483 & 6.562 & 1.045 \\
\hline ST-COM & 0 & 1 & 0.681 & 0.012 \\
\hline
\end{tabular}

The table presents the descriptive statistics of the determining factors of the profitability of Islamic banks over the period from 2005 to 2018. The ROA has an average value of $3.781 \%$ and varies between -0.1156 and 0.1865 with a standard deviation of 2.0746. This ratio tells us about the overall profitability of Islamic banks.

The capitalization varies between 0.083 and 0.656 and registers an average of 0.545 . This implies that Islamic banks are strongly solid and capitalized in the face of financial shocks. The quality of banking management registers an average value of 0.34 and scales between 0 and 0.724 with a standard deviation of 1.2434 . This implies that Islamic banks during the study period suffer from a lack of efficiency in terms of quality of management. Liquidity is on average 18,726\% and varies between 0 and 7,893. This tells us that liquidity is important in Islamic banks despite the disruption of economic conditions. Islamic bank has a low market share. On average, this ratio registers a value of 2.065 and ranges between 3.01 and 5.15. This ratio provides us with an idea of its role in boosting the economy.

The quality of service reaches an average value of $21 \%$ and varies between 17 and $33 \%$. An Islamic bank attaches importance to customer retention and adopts customer communication strategies.

The presence of the woman or the sexual gender records an average of $32 \%$ and balances between 12 and $44 \%$ of the employed workforce. For political and cultural considerations, the presence of women is of considerable importance and gives an idea of the degree of openness to female skills and their weight in Islamic banks. This factor allows for more creativity and productivity. Diversification averages 0.945 and reaches a maximum of 5.019. Islamic banks seek to diversify to improve their productivity and profitability. This requires adequate means and mechanisms to ensure this objective. Inflation has an average value of 5.016 and ranges between 3.452 and 12.543. The unstable macroeconomic conditions caused by the spread of corruption, the supreme crisis and the events of the spring in certain Arab countries weighed heavily on their economies. The size of the Islamic banks registers an average value of 6.562 and varies between 1.058 and 9.483. Large banks are more efficient than small banks.

Staff competence ranges from 0 to 1 , an average of $68 \%$. Islamic banks by attracting qualified personnel commit to training them by various means to achieve objectives related to productivity, survival, competitiveness and profitability.

Table 3. Pearson correlation matrix

\begin{tabular}{|c|c|c|c|c|c|c|c|c|c|c|c|}
\hline & $\begin{array}{l}\mathbb{\rho} \\
\stackrel{1}{1}\end{array}$ & 응 & $\stackrel{0}{\beth}$ & $\tilde{U}$ & $\sum_{\Sigma}^{\pi}$ & $\tilde{a}$ & 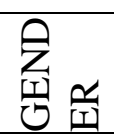 & $\vec{\theta}$ & 崩 & $\stackrel{\mathrm{I}}{\mathrm{N}}$ & 它 \\
\hline ROA & 1.000 & & & & & & & & & & \\
\hline QGB & 0.083 & 1.00 & & & & & & & & & \\
\hline $\begin{array}{l}\text { LIQ } \\
\end{array}$ & 0.043 & 0.671 & 1.00 & & & & & & & & \\
\hline
\end{tabular}




\begin{tabular}{|l|l|l|l|l|l|l|l|l|l|l|l|}
\hline CB & 0.324 & -0.151 & 0.179 & 1.00 & & & & & & & \\
\hline MSH & -0.351 & 0.674 & -0.039 & 0.538 & 1.00 & & & & & & \\
\hline QS & -0.337 & -0.476 & -0571 & -0.389 & 0.045 & 1.00 & & & & & \\
\hline $\begin{array}{l}\text { GEND } \\
\text { ER }\end{array}$ & 0.342 & 0.376 & 0.095 & 0.034 & 0.066 & 0.041 & 1.00 & & & & \\
\hline DIV & -0.506 & 0.023 & -0.275 & -0.093 & 0.527 & 0.115 & -0.073 & 1.000 & & & \\
\hline INF & 0.198 & 0.059 & -0.011 & 0.043 & 0.381 & - & 0.612 & -0.107 & 1.00 & & \\
\hline SIZE & 0.651 & 0.561 & 0.042 & -0.562 & $\begin{array}{l}- \\
0.018\end{array}$ & 0.623 & -0.143 & 0.301 & 0.106 & 1.00 & \\
\hline $\begin{array}{l}\text { ST- } \\
\text { COM }\end{array}$ & -0.483 & 0.642 & -0.007 & -0.471 & $\begin{array}{l}0.067 \\
3\end{array}$ & 0.394 & 0.223 & 0.573 & -0.431 & 0.005 & 1.00 \\
\hline
\end{tabular}

The aim of the Pearson correlation matrix table is to detect whether there is a multicollinearity problem between the variables introduced into our model. In this sense, Anderson and al (1990) have shown that any correlation coefficient greater than 0.7 indicates a potential problem. Ben Ali, (2017) sets a critical value equal to 0.7 from which a serious colinearity problem between the independent variables is pronounced.

The majority of variables are weakly correlated with each other. Our results indicate that the market share, the quality of service, the diversification and the skill of the workforce employed are negatively correlated with the return on ROA Assets. The quality of banking, liquidity, capitalization, gender, inflation and size seem to be positively correlated with ROA profitability. The correlation between the variables is generally accepted and poses no problem.

\section{Econometric estimation and interpretations of the results}

Table 4.Econometric estimation

\begin{tabular}{|l|c|c|c|}
\hline Variables & coef & $\mathrm{Z}$ & $\mathrm{P}>|\mathrm{z}|$ \\
\hline Constant & -0.176 & 1.762 & $0.081^{*}$ \\
\hline QGB & 1.824 & 4.903 & $0.000^{* * *}$ \\
\hline LIQ & -0.169 & -1.290 & $0.002^{* *}$ \\
\hline CB & 1.194 & 2.528 & $0.000^{* * *}$ \\
\hline MSH & 0.020 & 1.667 & $0.208(\mathrm{n} / \mathrm{s})$ \\
\hline QS & 2.520 & 1.076 & $0.012^{* *}$ \\
\hline Gender & 0.207 & 2.471 & $0.004 * *$ \\
\hline DIV & -0.017 & -0.84 & $0.031^{*} *$ \\
\hline INF & 0.012 & 1.323 & $0.188(\mathrm{n} / \mathrm{s})$ \\
\hline ZIZE & -0.156 & 1.312 & $0.243 \mathrm{n} / \mathrm{s}$ \\
\hline ST-COM & 0.003 & 3.258 & $0.000 * * *$ \\
\hline
\end{tabular}

$(*, * *, * * *:$ The coefficients are significant at the $10 \%, 5 \%$ and $1 \%$ thresholds, respectively)

The quality of bank management has a positive and significant impact on profitability ( $\mathrm{P}$ $>|Z|=0.00$ ). This implies that Islamic banks are efficient in the conduct of their operations and the management of their assets and means the ability of revenues to cover costs, which contributes to improving their profitability. 
Liquidity has a negative and significant impact on profitability $(\mathrm{P}>|\mathrm{Z}|=0.002)$. Islamic banks are subject to a lack of liquidity. They must have a level of liquid assets to meet their short-term commitments. This is justified by the absence of a secondary market on which banks can refinance in case of need. In this sense, they must constitute a reserve to protect themselves against a situation of illiquidity.

Capital adequacy has a positive and significant impact on profitability $(P>|Z|=0.00)$. This result reflects the ability of Islamic banks to withstand loss shocks at critical moments. The higher this ratio, the stronger the strength of Islamic banks against shocks.

Market share has a positive but not significant impact on profitability $(\mathrm{P}>|\mathrm{Z}|=0.208)$. Islamic banks seem to occupy a market share considered to be low. Generally, the best performing banks have a high market share.

The quality of services has a positive and significant impact on profitability $(P>|Z|=$ 0.012). This means that achieving high quality service means putting in place reliable strategies in order to improve customer confidence in the services offered. This allows the creation of an environment of innovation and creativity and more quality. Islamic banks have a vested interest in strengthening their communication strategy with their customers, which also contributes to improving their reputation.

The gender has a positive and significant impact on profitability $(\mathrm{P}>|\mathrm{Z}|=0.004)$. The presence of women among human resources is a favorable factor in improving the profitability of Islamic banks. Indeed, the mixed environment creates competition and motivation. In addition to the psychological effect, availability and patience, women have the mental and behavioral capacities to perform all the functions assigned to them, which improves the profitability of BI. In the Middle East and North Africa region, the majority of countries are adopting a proactive policy in favor of women's rights and the elimination of gender inequalities. The gender thus involves adopting and implementing innovative equity measures as well as human resources management based on skills and performance criteria.

Diversification has a negative and significant impact on profitability $(\mathrm{P}>|\mathrm{Z}|=0.031)$. This result is explained by the fact that the most diversified banks suffer a high degree of risk. Islamic banks do not have enough log experience to engage in diversification which can be a source of cost.

Inflation has a positive but not significant impact on profitability $(\mathrm{P}>|\mathrm{Z}|=0.188)$. Inflation depends on expectations. Islamic banks take a proactive view of the real economy that fights inflation.

Size has a negative but not significant impact on profitability $(P>|Z|=0.243)$. The sign of this variable is ambiguous in the literature. Generally, the larger the size of the banks, the more experience they have in promoting economies of scale and thus improving competitiveness and performance.

Staff competence has a positive and significant impact on profitability $(\mathrm{P}>|\mathrm{Z}|=0.000)$. This result implies that Islamic banks give importance to staff training in order to increase competitiveness and profitability. Otherwise, the lack of qualified and competent personnel exposes the Islamic bank to risks. Islamic banks are responsible for developing human capital, which manifests itself in individual and collective know-how.

\section{CONCLUSION}

The Islamic finance industry is growing in importance and attracting the attention of researchers. This phenomenon which draws its legitimacy from the precepts of Sharia prohibits usury or even 
"Riba" and adopts a sharing of risks and profits with customers and suppliers of Shariacompliant products. This study identifies the effect of internal and external factors on the Islamic banks' profitability operating in the Middle East and North Africa region from 2004 till 2018. The results show that the quality of bank management, capitalization, liquidity, quality of services, the presence of women and inflation are significant determinants of bank profitability.

Creating an environment for a virtuous cycle of entrepreneurship, innovation and economic growth and sustainable development depends on macroeconomic conditions and the management strategies adopted by Islamic banks to be able to improve their profitability.

Our study suffers from some limitations related to the heterogeneity of the data as well as the size of the sample considered reduced. With the addition of other factors related to audit and governance, our study can lead to more reliable and robust results.

\section{REFERENCES}

Abdel-Hameed M. B.(2003). Determinants of Profitability in Islamic Banks: Some Evidence from the Middle East, Islamic Economic Studies, 11(1), 31-57.

Abduh, M., \& A. Alias. (2014). Factors Determine Islamic Banking Performance in Malaysia: A Multiple Regression Approach, Journal of Islamic Banking and Finance, 31(1), 44-54.

Abduh, M., \& Y. Idrees, (2013). Islamic Bank Profitability: A Study of Islamic Bank in Malaysia, The International Journal of Business Review, 1(1), 51- 62.

Ahmed, A. (2010). Global financial crisis: an Islamic finance perspective, InternationalJournal of Islamic and Middle Eastern Finance and Management, 3(4),306-320.

Aisyah, M.(2018). Islamic Bank Service Quality and It's Impact on Indonesian Customers' Satisfaction and Loyalty, Al-Iqtishad Journal of Islamic Economics, 10(2), 367-388.

Alazzani, A., W. N., Wan-Hussin, \&M. Jones, (2019). Muslim CEO, women on boards and corporate responsibility reporting: some evidence from Malaysia, Journal of Islamic Accounting and Business Research, 10(2), 274-296.

Ali, M., \&S. A. Raza, (2017). Service quality perception and customer satisfaction in Islamic banks of Pakistan: the modified SERVQUAL model, Total Quality Management \& Business Excellence, 28(5-6), 559-577.

AlTamimi, H., H.A.\& H.Charif, (2011). Multiple approaches in performance assessment of UAE commercial banks, International Journal of Islamic and Middle Eastern Finance and Management, 4(1), 74-82.

Babalola, Y. A. (2012). The Determinants of Bank's Profitability in Nigeria, Journal of Money, Investment and Banking, Issue 24, 6-16.

Ben Ali, A. (2017). The Determinants of Tax Returns for Tax Officials: An Essay in the Tunisian Context, International Journal of Accounting and Financial Reporting, 7(2), 323-335.

Daoud, Y., \&et A. Kammoun, (2016). Les Déterminants De La Performance Des BanquesIslamiques, International Journal of Business \& Economic Strategy, 5(2), 2226.

Dodi, D., D, Supiyadi.,\& M. Arief, (2018). Islamic Bank Profitability: A Study of Islamic Bank in Indonesia, The international journal of Business Review, 1(1), 51-62.

Eljelly, A. M. A., \&A. A. Elobeed, (2013). Performance indicators of banks in a total Islamic banking system: the case of Sudan, International Journal of Islamic and Middle Eastern Finance and Management, 6(2), 142-155. 
Hanif, M., M. Tariq, A. Tahir., \& W. Momeneen, (2012). Comparative Performance Study of Conventional and Islamic Banking in Pakistan, International Research Journal of Finance \& Economics, 83, 62-72.

Haron, S. (1996). the effects of management policy on the performance of Islamic banks, Asia Pacific Journal of Management, 13(2), 63-76.

Hassan, T., S. Mohamad., \& M.K.I. Bader. (2009). Efficiency of conventional versus Islamic banks: evidence from the Middle East, International Journal of Islamic and Middle Eastern Finance and Management, 2(1), 46-65.

Iqbal, M., (2020). Islamic finance: An Attractive New Way of Financial Intermediation, International Journal of Banking and Finance,

Jadoon, A.U., Y. Guang., \&S. Ali, (2019). The Profitability Analysis of Islamic (Sukuk) vs. Conventional Financing: an Empirical Analysis, Journal of Business Management and Economic Research, 3 (2), 26-41.

Khan, M. M. S., \&F. Ijaz, (2014). Islamic Banking in Pakistan: Challenges and Opportunities A Performance Based Analysis, Islamic Banking and Finance Review Vol. $1 \mathrm{~N}^{\circ}$ 1, 49-70.

Khrawish, H. A., (2011). Determinants of commercial banks performance: evidence from Jordan, International Research Journal of Finance and Economics, 81, 148-159.

Munir, B., U. Salwa., \& A. Bustamam, (2017). Camel Ratio on Profitability Banking Performance (Malaysia Versus Indonesia), International Journal of Management, Innovation \& Entrepreneurial Research, 3(1), 30-39.

Ougoujil, S., \&S. M.,Rigar, (2018). Ethical Finance and Islamic Finance: Particularities, Possible Convergence and Potential Development, International Journal of Economics and Management Engineering, 12(7), 982-996.

Petria, N., B. Capraru., \& I. Ihnatov. (2015). Determinants of banks' profitability: evidence from EU 27 banking systems, Procedia Economics and Finance, 20, 518 - 524.

Samad A. (2004). Performance of interest-free Islamic banks vis-a-vis interest-based conventional banks of Bahrain, Journal of Economics and Management, 12(2), 12-25.

Short, B. K. (1979). The relation between commercial bank profit rates and banking concentration in Canada, Western Europe, and Japan, Journal of banking \& Finance, 3(3), 209-219.

Sinha, C. (2020). Women in the Bahrain Financial Sector: Opportunities, Challenges and Strategic Choices, Social Change, 50(1), 44-60.

Srairi S.A. (2009). Factors influencing the profitability of conventional and Islamic commercial banks in GCC countries. Review of Islamic Economics, 13(1), 5-30.

Sufian, F. (2010). Does foreign presence foster Islamic banks' performance? Empirical evidence from Malaysia, Journal of Islamic Accounting and Business Research, 1(2), 128- 147.

Sufian, F., \& M. S. Habibbullah, (2009). Bank Specific and macroeconomic determinants of bank profitability: Empirical evidence from the China banking sector, Frontiers of Economics in China, 4(2), 274-291.

Sufian, F., \&M.S. Habibullah, (2009). Determinants of bank profitability in a developing economy: empirical evidence from Bangladesh, Journal of Business Economics and Management, 10(3), 207-217.

Sufian, F., \&M.S. Habibullah, (2010). Assessing the Impact of Financial Crisis on Bank Performance: Empirical Evidence from Indonesia, ASEAN Economic BulletinVolume 27(3), 245-262. 
Supiyadi, D., M. Arief.,\& N. Nugraha, (2019). The Determinants of Bank Profitability: Empirical evidence from Indonesian Sharia Banking Sector, Advances in Economics, Business and Management Research, 65, 21-26.

Wasiuzzaman, S. (2014). Analysis of corporate cash holdings of firms in Malaysia, Journal of Asia Business Studies, 8(2), 118-135.

Wasiuzzaman, S., \& U. N. Gunasegavan. (2013).Comparative study of the performance of Islamic and conventional banks: The case of Malaysia, Humanomics, 29(1), $43-60$.

Zarrouk, H., K. B. Jedidia, \& M. Moualhi. (2016). Is Islamic bank profitability driven by same forces as conventional banks?,International Journal of Islamic and Middle Eastern Finance and Management, 9(1), 46 - 66.

\section{Copyrights}

Copyright for this article is retained by the author(s), with first publication rights granted to the journal. This is an open-access article distributed under the terms and conditions of the Creative Commons Attribution license (http://creativecommons.org/licenses/by/4.0/) 